\title{
Deterioration and fermentability of energy cane juice
}

\author{
Sandra Regina Ceccato-Antonini ${ }^{{ }^{*}}$ Ana Paula Guarnieri Bassi ${ }^{1}$ \\ Anna Livia Paraluppi ${ }^{1}$ Eder Gustavo Dias dos Santos ${ }^{2}$ Sizuo Matsuoka ${ }^{2}$
}

${ }^{1}$ Departamento Tecnologia Agroindustrial e Socio-Economia Rural, Centro de Ciências Agrárias, Universidade Federal de São Carlos (UFSCar), Via Anhanguera, km 174, 13600-970, Araras, SP, Brasil. E-mail: antonini@cca.ufscar.br. "Corresponding author.

${ }^{2}$ Vignis Ltda, Fazenda São Pedro, Santo Antonio de Posse, SP, Brasil.

\begin{abstract}
The main interest in the energy cane is the bioenergy production from the bagasse. The juice obtained after the cane milling may constitute a feedstock for the first-generation ethanol units; however, little attention has been dedicated to this issue. In order to verify the feasibility of the energy cane juice as substrate for ethanol production, the objectives of this research were first to determine the microbiological characteristics and deterioration along the time of the juices from two clones of energy cane (Type I) and second, their fermentability as feedstock for utilization in ethanol distilleries. There was a clear differentiation in the bacterial and yeast development of the sugarcane juices assayed, being much faster in the energy canes than in sugarcane. The storage of juice for 8 hours at $30^{\circ} \mathrm{C}$ did not cause impact in alcoholic fermentation for any sample analyzed, although a significant bacterial growth was detected in this period. A decrease of approximately seven percentage points in the fermentative efficiency was observed for energy cane juice in relation to sugarcane in a 24-hour fermentation cycle with the baking yeast. Despite the faster deterioration, the present research demonstrated that the energy cane juice has potential to be used as feedstock in ethanol-producing industries. As far as we know, it is the first research to deal with the characteristics of deterioration and fermentability of energy cane juices.
\end{abstract}

Key words: bioenergy, biomass, renewable energy, ethanol $1 G$.

Deterioração e fermentabilidade do caldo de cana energia

RESUMO: O principal interesse na cana energia reside na produção de bioenergia a partir do bagaço. O caldo obtido após a moagem da cana pode se constituir em substrato para as unidades de produção de etanol de primeira geração, no entanto, pouca atenção tem sido dispensada a esta questão. O presente trabalho avaliou o caldo de cana energia obtido de dois clones Tipo I como substrato para a produção de etanol, com base na determinação das suas características microbiológicas e deterioração ao longo do tempo, em comparação com o caldo de cana-de-açúcar (variedade RB867515). Foi observada uma clara diferenciação quanto ao crescimento bacteriano e de leveduras nas amostras de caldo analisadas, sendo o crescimento mais rápido no caldo de cana energia que no caldo de cana-de-açúcar. A manutenção do caldo por 8 horas a $30^{\circ} \mathrm{C}$ não causou impacto sobre a fermentação etanólica para quaisquer das amostras analisadas, apesar do crescimento significativo de bactérias. Houve um decréscimo de aproximadamente sete pontos percentuais na eficiência da fermentação com caldo de cana energia em um ciclo fermentativo de 24 horas com a levedura da panificação, em relação ao caldo da cana-de-açúcar. Apesar de a deterioração do caldo da cana energia ter sido mais rápida que a apresentada pelo caldo de cana-de-açúcar, o presente trabalho demonstrou que o caldo de cana energia tem potencial para ser utilizado como substrato nas indústrias produtoras de etanol. Do que se tem conhecimento, esse é o primeiro trabalho que trata das características de deterioração e fermentabilidade do caldo de cana energia.

Palavras-chave: bioenergia, biomassa, energia renovável, etanol $1 G$.

\section{INTRODUCTION}

Bioenergy derived from biomass is an alternative form of renewable energy to lessen the petroleum usage (SOUZA et al., 2015); although, contentious (HABERL et al., 2013; COELHO \& GOLDEMBERG, 2013). Ethanol derived from sugarcane in Brazil and from corn in the USA as liquid combustible replacing gasoline is a positive example to give significant contribution to mitigate part of the greenhouse gas (GHG) emitted by cars (GOLDEMBERG, 2013; WALTER et al., 2014).

Unlike sugarcane, its variant 'energy cane' is a plant that thrives better in less fertile soils and in less favorable environmental conditions, having potential to produce more than two-fold biomass per unit area and time under equal conditions. Energy cane appears as a valuable alternative 
feedstock for bioenergy, at least for tropical countries (ALEXANDER, 1985; MATSUOKA et al., 2014). Botanically, the fundamental distinguishing characteristic of energy cane in comparison with conventional sugarcane is its genomic constitution. Whereas the modern sugarcane cultivars have a predominance (about $85 \%$ ) of genome from the basic species Saccharum officinarum, with the remainder coming from the wild ancestor $S$. spontaneum (D'HONT et al., 1996; GRIVET \& ARRUDA,2001; CUADRADO et al., 2004), energy cane types have something the inverse of that (GOUY et al., 2015). Besides, the higher agronomical potential of energy cane by the technological side, a striking difference from sugarcane lies in the carbohydrate components: energy cane has a juice comparatively with less total sugars (sucrose is the predominant form) and; conversely, a much higher fiber content.

TEW \& COBIL (2008) described two categories of energy canes, Type I and Type II. The first is a type closer to the conventional sugarcane but comparatively presenting lower sucrose content and higher fiber content, whereas Type II has still higher fiber content and almost no sugar at all, and for that reason, to be used exclusively for biomass exploitation. In between those extremes, all distinct sucrose and fiber tradeoff is presented by a segregant population of a cross between ancestors (RAMDOYAL \& BADALOO, 2007; WANG et al., 2008; SANTCHURN et al., 2012).

Type I energy cane can be exploited by conventional sugar cane distilleries to produce first generation ethanol (EG1) from its juice, along with steam and electric power from the bagasse (ALEXANDER, 1985; RAO et al., 2007; MATSUOKA et al., 2014). For industries other than ethanol-producing plants, which are interested only in the bagasse to feed boilers, the energy cane juice remains as a side-product with high value as a fermentable broth, even higher than the bagasse per se. However, the fermentation characteristics of energy cane juice have been seldom evaluated, except for the research by ALEXANDER (1985), which considered it suitable for ethanol production.

Therefore, the objectives of this research were first to determine the microbiological characteristics of juice from two clones of energy cane (Type I) and second, their fermentability as feedstock for utilization in ethanol distilleries. Additionally, the deterioration of the juices along the time was evaluated as well. Results obtained for energy cane were compared to the sugarcane conventional variety RB867515, which is a medium-ripening cultivar recommended to be cut from the middle to the end of the harvest season in CentralSouthern Brazil (BARBOSA et al., 2001).

\section{MATERIAL AND METHODS}

Juices of two clones of energy cane (Type I) and one of conventional sugarcane (VG11-X1, VG11-X2 and RB867515, respectively) were used in this study, which were planted in June 2012 and harvested at 12 February 2014 for the experiments.

Samples were collected at the Vignis Experimental Station, located in Santo Antonio de Posse-SP, Brazil (Lat. 22³5'07.92’'S; Long. $\left.46^{\circ} 58^{\prime} 45^{\prime \prime} \mathrm{W}\right)$. Each sample was extracted from a bulk of twenty entire stalks (stalk + top + leaves), and then sent to the laboratories for analysis. Process of disintegration, mixing and pressing to extract the juice was carried out according to the methods established by CONSECANA (2006).

Juice used in the microbiological and fermentation analyses was extracted based on the methodology of TANIMOTO (1964), which was collected in sterilized screw-cap storage bottles, in duplicate for each sample, refrigerated and sent to the laboratory to be processed within an one-hour interval.

Juices were maintained in an incubator at $30^{\circ} \mathrm{C}$ and samples were collected at $0,4,8,24,30$ and 48 hours after extraction. For the microbiological analysis, the samples were serially diluted in saline solution $(\mathrm{NaCl} 0.85 \% \mathrm{w} / \mathrm{v})$ and poured onto three culture media for colony counting (Colony-Forming Unit $\mathrm{mL}^{-1}$ or $\mathrm{CFU} \mathrm{mL}^{-1}$ ). Bacteria numbers were determined in Nutrient Agar $\left(5 \mathrm{~g} \mathrm{~L}^{-1}\right.$ bacteriological peptone, $3 \mathrm{~g} \mathrm{~L}^{-1}$ meat extract, $1 \mathrm{~g} \mathrm{~L}^{-1}$ sodium chloride and $20 \mathrm{~g} \mathrm{~L}^{-1}$ agar, in distilled water, with nystatin to a final concentration of $10 \mathrm{mg} \mathrm{L}^{-1}$ ), incubating the Petri dishes at $30^{\circ} \mathrm{C}$ for 48 hours. Number of total yeasts was determined in YPD medium $\left(10 \mathrm{~g} \mathrm{~L}^{-1}\right.$ yeast extract, $20 \mathrm{~g} \mathrm{~L}^{-1}$ glucose, $20 \mathrm{~g} \mathrm{~L}^{-1}$ bacteriological peptone and $20 \mathrm{~g} \mathrm{~L}^{-1}$ agar, in distilled water, with chloramphenicol and tetracycline to a final concentration of $10 \mathrm{mg} \mathrm{L}^{-1}$ each), incubated at $30^{\circ} \mathrm{C}$ for 72 hours. For non-Saccharomyces yeasts, Lysine agar (with antibiotics) was utilized (WALTERS \& THISELTON, 1953 modified by MORRIS \& EDDY, 1957), with incubation at $30^{\circ} \mathrm{C}$ for 72 hours.

The juices stored at $0,8,24$ and 48 hours at $30^{\circ} \mathrm{C}$ were considered for the fermentation tests, which were carried out in sterilized $250 \mathrm{~mL}$ Erlenmeyer flasks with $100 \mathrm{~mL}$ of final juice volume, in duplicate, $8-10 \% \mathrm{w} / \mathrm{v}$ of commercial baking yeast, at $30^{\circ} \mathrm{C}$, without shaking. The initial cell number varied from 5 to $9 \times 10^{8}$ cells $\mathrm{mL}^{-1}$. Fermentation broth 
was sampled in intervals of 0,12 and 24 hours after yeast inoculation to verify the yeast viability under optical microscopy (proportion of living cells in relation to the total number of cells, after coloration with methylene blue), according to LEE et al. (1981). Fermented broth was centrifuged at 3,400rpm for 5 minutes and the supernatant was analysed for $\mathrm{pH}$ using a digital $\mathrm{pH}$-meter; for total residual reducing sugars $\left(\mathrm{g} 100 \mathrm{~mL}^{-1}\right)$, by the method of dinitrosalycilic acid after hydrolysis of the sample with hydrochloric acid (MILLER, 1959); for alcohol concentration, determined in a digital densimeter Anton-Paar ( $\mathrm{g}$ $\left.100 \mathrm{~mL}^{-1}\right)$ in the hydroalcoholic solution obtained by samples distillation. The fermentative efficiency (\%) was calculated considering the ethanol yield of the assay ( $\mathrm{g}$ alcohol produced $\mathrm{g}^{-1}$ reducing sugars consumed) in relation to the theoretical value of $0.511 \mathrm{~g}$ alcohol g ${ }^{-1}$ sugars (HATZIS et al., 1996).

In the energy cane juices, the determination of purity $(\%)$, Pol $(\%)$, Brix, total reducing sugars $\left(\mathrm{g} 100 \mathrm{~mL}^{-1}\right)$ and fiber $\left(\mathrm{g} 100 \mathrm{~g}^{-1}\right)$ were processed according to CONSECANA (2006).

Results of microbiological analysis (data were transformed to $\log _{10}$ ) were submitted to two-way analysis of variance to verify differences among the juice storage times and each type of cane plants, as well as their interaction. When significant differences were detected, the Scott-Knott multiple comparison test was applied to compare the averages, at $5 \%$ of significance level, using the software SASM-Agri.

\section{RESULTS AND DISCUSSION}

Initially, cane samples were compared concerning Brix, Pol, purity, sugar and fiber contents (Table 1). The energy cane variety VG11-X1 presented the highest sugar content and Brix value and conversely, VG11-X2 presented the highest fiber content. Results for the sugarcane variety RB867515 were intermediate between the energy canes for Brix, Pol and sugars, but it presented the lowest fiber content. Type I energy cane is focused on sugar and fiber, with the same or similar sugar quality characteristics reported in sugarcane (PATERSON et al., 2013). However, there was difference in the sugar and fiber contents between the Type I varieties, with the variety VG11-X2 more adequate for energy purposes because of the higher fiber content and lower sugar concentration.

However, in spite of the differences in sugar content between the varieties of energy cane, the deterioration was similar concerning juice $\mathrm{pH}$ and sugar concentration along 48 hours of storage at $30^{\circ} \mathrm{C}$. Less than $1 \mathrm{~g} 100 \mathrm{~mL}^{-1}$ of total reducing sugars were detected after 48 hours and $\mathrm{pH}$ varied from 5.5 to around 4.0. Alcohol was also detected in the juice stored for 48 hours $\left(2.8-4.3 \mathrm{~g} 100 \mathrm{~mL}^{-1}\right)$. These results were not observed in the sugarcane juice, except for the $\mathrm{pH}$, showing a very slower deterioration compared to energy cane juices (Table 2). This deterioration may be the result of the growth of native microorganisms, which may differ in number and diversity in energy canes and sugarcane. In the juice of energy cane VG11-X1, the highest bacteria number was verified after 8 hours of storage at $30^{\circ} \mathrm{C}$ (100-fold increase), and a significant decrease after 30 hours (Figure 1A). For the variety VG11-X2, the peak of bacterial growth occurred in 24 hours of storage (1000-fold increase), decreasing significantly afterwards (Figure 1B). In sugarcane juice, the highest bacteria number was observed in 48 hours of storage, a 1000-fold increase. Sharp decrease occurred in 30 hours followed by a significant increase may be related to a more diverse bacterial community resulting in the replacement of some initial competitive species by others according to the changes in the physico-chemical environment (Figure 1C). Anyway, the bacterial development was faster in energy cane juices than in the sugarcane juice, which may contribute to the faster deterioration in energy canes. The bacterial growth may be also responsible for the substantial decrease in juice $\mathrm{pH}$ from 5.5 to around 4.0 within 24 hours of storage

Table 1 - Composition of the energy and sugar canes.

\begin{tabular}{|c|c|c|c|c|c|}
\hline Sample & ${ }^{\circ}$ Brix $^{1}$ & $\operatorname{Pol}(\%)^{1}$ & Purity $(\%)^{1}$ & $\begin{array}{l}\text { Total reducing sugars } \\
\qquad\left(\mathrm{g} 100 \mathrm{~mL}^{-1}\right)^{1}\end{array}$ & Fiber $\left(\mathrm{g} 100 \mathrm{~g}^{-1}\right)^{2}$ \\
\hline Energy cane (VG11-X1) & 16.1 & 12.0 & 74.5 & 19.5 & 13.8 \\
\hline Energy cane (VG11-X2) & 12.5 & 7.4 & 58.9 & 13.2 & 20.3 \\
\hline Sugarcane (RB867515) & 14.4 & 10.9 & 75.7 & 14.9 & 12.5 \\
\hline
\end{tabular}

${ }^{1}$ In cane juice. ${ }^{2}$ In cane stalk. 
Table 2 - Fermentation tests utilizing the juice extracted from the energy cane clones VG11-X1 and VG11-X2 (Type I) and from the sugarcane variety $\mathrm{RB} 867515$ stored at $30^{\circ} \mathrm{C}$ for periods of $0,8,24$ and 48 hours. Fermentation was carried out by the baking yeast, at $30^{\circ} \mathrm{C}$, and samples were collected at 0 and 24 hours of fermentation.

\begin{tabular}{|c|c|c|c|c|c|c|c|c|c|c|}
\hline \multirow{2}{*}{ Sample } & \multirow{2}{*}{$\begin{array}{l}\text { Storage } \\
\text { time (h) }\end{array}$} & \multicolumn{2}{|c|}{-Cell viability (\%)- } & \multicolumn{2}{|c|}{--------pH------- } & \multicolumn{2}{|c|}{-Alcohol $\left({\left.\mathrm{g} 100 \mathrm{~mL}^{-1}\right)-}^{-}\right.$} & \multicolumn{2}{|c|}{$---\operatorname{TRRS}^{1}\left(\mathrm{~g} 100 \mathrm{~mL}^{-1}\right)---$} & \multirow{2}{*}{$\begin{array}{c}\text { Efficiency } \\
(\%)^{2}\end{array}$} \\
\hline & & $0 \mathrm{~h}$ & $24 \mathrm{~h}$ & $0 \mathrm{~h}$ & $24 \mathrm{~h}$ & $0 \mathrm{~h}$ & $24 \mathrm{~h}$ & $0 \mathrm{~h}$ & $24 \mathrm{~h}$ & \\
\hline \multirow{4}{*}{ VG11-X1 } & 0 & 97.4 & 99.8 & 5.56 & 4.36 & 0 & 5.1 & 19.45 & 1.44 & \multirow{4}{*}{54.9} \\
\hline & 8 & 98.7 & 99.7 & 5.08 & 4.54 & 0 & 5.4 & 14.19 & 0.33 & \\
\hline & 24 & 100 & 100 & 4.06 & 4.24 & 0 & 4.5 & 14.77 & 0.30 & \\
\hline & 48 & 100 & 98.4 & 4.06 & 4.24 & 4.3 & 5.7 & 0.79 & 0.26 & \\
\hline \multirow{4}{*}{ VG11-X2 } & 0 & 98.2 & 100 & 5.50 & 4.59 & 0 & 3.6 & 13.18 & 0.53 & \multirow{4}{*}{56.1} \\
\hline & 8 & 99.0 & 100 & 5.29 & 4.66 & 0 & 3.5 & 12.68 & 0.35 & \\
\hline & 24 & 99.6 & 100 & 4.13 & 4.17 & 0 & 2.8 & 12.16 & 0.54 & \\
\hline & 48 & 98.4 & 99.7 & 3.98 & 4.03 & 2.8 & 2.9 & 0.70 & 0.49 & \\
\hline \multirow{4}{*}{ RB867515 } & 0 & 99.7 & 93.5 & 5.45 & 4.52 & 0 & 4.7 & 14.88 & 0.16 & \multirow{4}{*}{62.7} \\
\hline & 8 & 99.8 & 99.9 & 5.44 & 4.53 & 0 & 3.9 & 12.38 & 0.22 & \\
\hline & 24 & 98.8 & 99.3 & 4.18 & 4.39 & 0 & 3.7 & 11.97 & 0.43 & \\
\hline & 48 & 99.8 & 99.6 & 3.75 & 4.03 & 0.3 & 3.5 & 10.90 & 0.36 & \\
\hline
\end{tabular}

${ }^{1}$ Total residual reducing sugars $\left(\mathrm{g} 100 \mathrm{~mL}^{-1}\right)$

${ }^{2}$ Fermentative efficiency (\%) was calculated with the results obtained after 24 hours of fermentation using juices newly extracted (0h storage time).

(Table 1) due to the production of organic acids (SINGH et al., 2006), especially by lactic acid bacteria (SOLOMON, 2000).

Similarly, the number of total yeasts in the juice of variety VG11-X1 increased also faster along the storage time, showing the peak at 30 hours of storage (Figure 1D), while for the juice of VG11-X2 the peak occurred at 48 hours (Figure $1 \mathrm{E})$. A much slower rate of increase in yeast number was observed for the sugarcane variety (Figure 1F). Regardless the samples, a 1000-fold increase in yeast number within 48 hours of storage at $30^{\circ} \mathrm{C}$ has occurred (Figures $1 \mathrm{D}, \mathrm{E}$ and $\mathrm{F}$ ). The nitrogen content in the juice is known to be $40 \%$ higher in energy canes than in sugarcane (data not published) and this condition may have favored the microbial development and accelerated the juice deterioration. Another important issue to be further evaluated is the microbial diversity in the juices of energy canes compared to sugarcane. Differences in the competitive and physiological characteristics of the microorganisms may also contribute to the differences observed in this study regarding the deterioration.

The number of non-Saccharomyces yeasts increased progressively until 30 hours of storage in the juices of energy canes (Figures $1 \mathrm{G}$ and $\mathrm{H}$ ) as it can be also seen in the results for total yeast number, which was coincident with the substantial decrease in sugar concentration after 24 hours of juice storage (Table 2). However, as only non-Saccharomyces number decreased further, it is expected the number of Saccharomyces should have increased the population from 30 to 48 hours of juice storage. For the sugarcane variety, the difference in number between total yeasts and non-Saccharomyces yeasts was not observed until 30 hours and it was minimal after 48 hours of storage (Figure 1I).

The effect of microbial deterioration upon the juice fermentability depended on the juice sample and on the storage time. For the variety VG11-X1, the yeast viability was not affected by the juice storage time; however, there was a decrease in $\mathrm{pH}$ (from 5.56 to 5.08) and in total residual reducing sugars (from

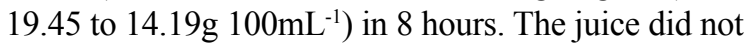
present deterioration that compromised the alcoholic fermentation within 8 hours of storage (Table 2). The decrease in juice $\mathrm{pH}$ in 8 hours of storage may be credited to the bacterial development (Figure 1A), as already discussed. For both conventional and VG11-X2 varieties, similar results were observed; although, the decrease in $\mathrm{pH}$ and in total residual reducing sugars 


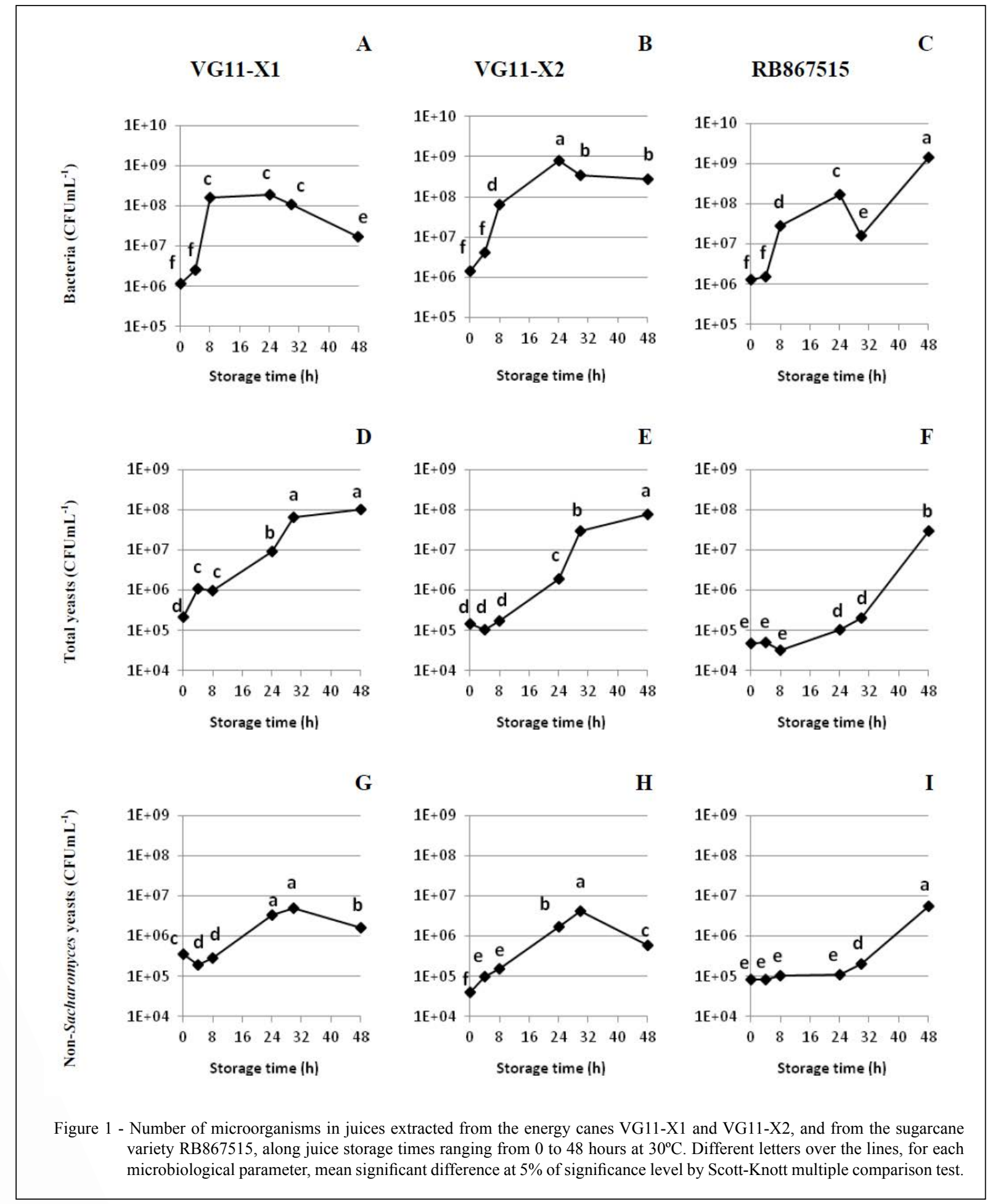

was lower than for VG11-X1 (Table 2). The growth of bacteria and yeasts in those samples was slower compared to the VG11-X1, as discussed before.
When the juice was stored for 24 hours, the alcohol content in the fermentation broth decreased for all samples. With 48 hours of storage, there was a natural 
fermentation (carried out by the native yeasts) in such a way that when the baking yeast was inoculated, as few as $0.70-0.79 \mathrm{~g} 100 \mathrm{~mL}^{-1}$ of total reducing sugars and as much as 2.8 to $4.3 \mathrm{~g} 100 \mathrm{~mL}^{-1}$ of alcohol were observed at the start of the fermentation, but only for the energy cane juices. The major effect on fermentation was thus due to the increase in yeast number, especially Saccharomyces, from 8 to 24 hours of juice storage.

A decrease of approximately seven percentage points (from $63 \%$ to $55-56 \%$ ) in the fermentative efficiency was observed for sugarcane juice in relation to the varieties of energy canes in a 24-hour fermentation cycle with the baking yeast (Table 2), in the samples newly collected. Although theoretical evaluations of ethanol production from juice of energy cane are reported (KIM \& DAY, 2011), to our knowledge, there is no data on the fermentative efficiency of energy cane juice so far. The decrease in the fermentative efficiency would be relevant if the juice of energy sugarcane was to be used as the main feedstock for ethanol-producing industries (BASSO et al., 2008), but this is not the case. The main application of energy cane is to obtain bagasse for boilers, or to make ethanol $2 \mathrm{G}$, at best. The present research demonstrated that the juice of energy cane is quite suitable for fermentation, despite the characteristic bacterial and yeast profiles. Additionally, knowing the profile of the juice under storage is important because when a distillery plant is running, the interruption of the process of fermentation may occur by any cause, mainly in new plants operated by beginners with not enough skill. This study showed that a storage of juice for 8 hours do not significantly affect the fermentation performance for energy cane.

\section{CONCLUSION}

The storage of juice for 8 hours at $30^{\circ} \mathrm{C}$ does not cause impact in alcoholic fermentation for any sample analyzed, although a significant bacterial growth is detected in this period. A decrease of seven percentage points in the fermentative efficiency is observed for energy cane juice in relation to the variety of sugarcane in a 24-hour fermentation cycle with the baking yeast. Despite the faster deterioration, the present research demonstrates that the energy cane juice has potential to be used as feedstock in ethanol-producing industries.

\section{REFERENCES}

ALEXANDER, A.G. The energy cane alternative. Amsterdam: Elsevier, 1985. 509p.
BARBOSA, M.H.P. et al. RB867515 sugarcane cultivar. Crop Breeding and Applied Biotechnology, v.1, n.4, p.437-438, 2001. Available from: $<$ http://www.canaufv.com.br/pdf_cultivares/ano $\% 20$ 1998\%20RB867515.pdf>. Accessed: Jun.19, $201 \overline{7}$.

BASSO, L.C. et al. Yeast selection for fuel ethanol production in Brazil. FEMS Yeast Research, v.8, p.1155-1163, 2008. Available from: $<$ http:// onlinelibrary.wiley.com/doi/10.1111/j.1567-1364.2008.00428.x/epdf\$. Accessed: Jun. 19, 2017. doi: 10.1111/j.1567-1364.2008.00428.x.

COELHO, S.T.; GOLDEMBERG, J. Global energy policy: a view from Brazil. In: GOLDTHAU, A. The handbook of global energy policy. VI - Regional perspectives on global energy. New York: Wiley, 2013. p.457-476.

CONSECANA. Manual de instruções. 5.ed. Piracicaba: Consecana, 2006. 112p.

CUADRADO, A. et al. Genome remodelling in three modern $S$. officinarum x $S$. spontaneum sugarcane cultivars. Journal of Experimental Botany, v.55, n.398, p.847-854, 2004. Available from: $<$ https://academic.oup.com/jxb/article/55/398/847/468029/Genomeremodelling-in-three-modern-S-officinarum-S $>$. Accessed: Jun. 19, 2017. doi: $10.1093 / \mathrm{jxb} / \mathrm{erh} 093$.

D'HONT, A. et al. Characterization of the double genome structure of modern sugarcane cultivars (Saccharum spp.) by molecular cytogenetics. Molecular Genetics and Genomics, v.250, p.405-413, 1996.

GOLDEMBERG, J. Sugarcane ethanol: strategies to a successful program in Brazil. In: LEE, W. Advanced biofuels and bioproducts. New York: Springer, 2013. p.13-20.

GOUY, M. et al. Site and Saccharum spontaneum introgression level drive sugarcane yield component traits and their impact on sucrose yield in contrasting radiation and thermal conditions in La reunion. Field Crops Research, v.171, p.99-108, 2015. Available from: <http:/www. sciencedirect.com/science/article/pii/S0378429014003086?via\%3Dihub>. Accessed: Jun. 19, 2017. doi: 10.1016/j.fcr.2014.11.002.

GRIVET, L.; ARRUDA, P. Sugarcane genomics: depicting the complex genome of animportant tropical crop. Current Opinion in Plant Biology, v.5, n.2, p.122-127, 2002. Available from: <http://www.sciencedirect. com/science/article/pii/S1369526602002340?via\%3Dihub $>$. Accessed: Jun. 19, 2017. doi: 10.1016/S1369-5266(02)00234-0.

HABERL, H. et al. Bioenergy: how much can we expect for 2050 ? Environmental Research Letters, v.8, 031004, 2013. Available from: $<\mathrm{http}$ ///iopscience.iop.org/article/10.1088/1748-9326/8/3/031004/ meta>. Accessed: Jun. 19, 2017. doi: 10.1088/1748-9326/8/3/031004.

HATZIS, C. et al. Detailed material balance and ethanol yield calculations for the biomass-to-ethanol conversion process. Applied Biochemistry and Biotechnology, v.57-58, n.1, p.443-459, 1996. doi: 10.1007/BF02941725.

KIM, M.; DAY, D.F. Composition of sugar cane, energy cane, and sweet sorghum suitable for ethanol production at Louisiana sugar mills. Journal of Industrial Microbiology and Biotechnology, v.38, n.7, p.803-807, 2011. Available from: <https://link.springer.com/art icle/10.1007\%2Fs10295-010-0812-8>. Access: Jun. 19, 2017. doi: $10.1007 / \mathrm{s} 10295-010-0812-8$.

LEE, S.S. et al. Rapid determination of yeast viability. Biotechnology and Bioengineering, v.11, p.641-649, 1981. 
MATSUOKA, S. et al. Energy cane: its concept, development, characteristics, and prospects. Advances in Botany, v.2014 Article ID 597275, 2014. Available from: <https://www.hindawi. com/archive/2014/597275/>. Accessed: Jun. 19, 2017. doi: $10.1155 / 2014 / 597275$

MILLER, G.L. Use of dinitrosalicylic acid reagent for determination of reducing sugar. Analytical Chemistry, v.31, p.426, 1959.

MORRIS, E.O.; EDDY, A.A. Method for the measurement of wild yeast infection in pitching yeast. Journal of the Institute of Brewing, v.63, n.1, p.34-35, 1957.

PATERSON, A.H. et al. The gene pool of Saccharum species and their improvement. In: PATERSON, A.H. Genomics of the Saccharinae. New York: Springer, 2013. p.43-72.

RAMDOYAL, K.; BADALOO, M.G.H. An evaluation of interspecific family of different nobilized groups in contrasting environments for breeding novel sugarcane clones for biomass. Proceedings of the International Society of Sugar Cane Technology, v.26, p.632-645, 2007.

RAO, P.S. et al. New sugarcane varieties and year round sugar and alcohol production with bagasse-based cogeneration in Barbados and Guiana. Proceedings of the International Society of Sugar Cane Technology, v.26, p.1169-1176, 2007.

SANTCHURN, D. et al. From sugar industry to cane industry: investigations on multivariate data analysis technique in the identification of different high biomass sugarcane varieties. Euphytica, v.185, p.543558, 2012. Available from: <http://www.academia.edu/26456012/
Euphytica_International_Journal_of_Plant_Breeding $>$. Accessed: Jun. 19, 2017. doi: $10.1007 / \mathrm{s} 10681-012-0682-4$.

SINGH, I. et al. Post-harvest quality deterioration of cane juice: physico-biochemical indicators. Sugar Tech, v.8, n.2, p.128-131, 2006. doi: 10.1007/BF02943646.

SOLOMON, S. Post-harvest cane deterioration and its milling consequences. Sugar Tech, v.2, n.1, p.1-18, 2000. doi: 10.1007/ BF0294374.

SOUZA, G.M. et al. SCOPE Bioenergy \& sustainability - Technical summary. In: . Bioenergy and sustainability: bridging the gaps. São Paulo: SCOPE/FAPESP, 2015. p.8-27.

TANIMOTO, T. The press method of cane analysis. Hawaiian Planters' Record, v.57, p.133-150, 1964.

TEW, T.L.; COBIL, R.M. Genetic improvement of sugarcane (Saccharum spp) as an energy crop. In: VERMERRIS, W. Genetic improvement of bioenergy crops. New York: Springer, 2008. p.249-272.

WALTER, A. et al. Brazilian sugarcane ethanol: development so far and challenges for the future. WIREs Energy and Environment, v.3, p.70-92, 2014. doi: 10.1002/wene.87.

WALTERS, L.S.; THISELTON, M.R. Utilization of lysine by yeasts. Journal of the Institute of Brewing, v.59, p.401, 1953.

WANG, L.P. et al. Evaluation of sugarcane x Saccharum spontaneum progeny for biomass composition and yield components. Crop Science, v.48, p.951-961, 2008. doi: 10.2135/cropsci2007.10.0555. 